\title{
UPAYA MENINGKATKAN KEMAMPUAN SISWA TERHADAP PENGUASAAN KONSEP ENERGI PANAS BIDANG STUDI IPA MELALUI MODEL PEMBELAJARAN SKRIP KOOPERATIF DI KELAS VIA SDN 105292 PERCUT SEI TUAN
}

\author{
Mesrawati \\ Surel: mesrawati@yahoo.com
}

\begin{abstract}
ABSTRAK
Penelitian tindakan kelas ini bertujuan untuk mengetahui peningkatan pemahaman dan respon siswa kelas IVa semester ganjil SDN 105292 Percut Sei Tuan dalam memahami materi Energi Panas melalui penerapan strategi pembelajaran skrip Kooperatif. Penelitian ini dilaksanakan dengan menggunakan metode kualitatif interaktif yang dilakukan dengan 3 siklus. Subyek penelitian ini adalah siswa kelas IVa semester SDN 105292 Percut Sei Tuan. Sedangkan obyeknya adalah strategi Skrip Kooperatif. Berdasarkan analisis data dapat disimpulkan bahwa pada siklus 1 ketuntasan belajar siswa pada materi ini nilai rata-rata hanya 66,00, sedangkan pada siklus 2 dengan menerapkan strategi pembelajaran Skrip Kooperatif meningkat mencapai nilai rata-rata 72,42. Dan pada siklus 3 nilai rata-rata meningkat menjadi 83,00. Respon siswa juga meningkat, data hasil observasi terhadap aktifitas siswa dari $52,08 \%$ pada siklus 1 , meningkat pada siklus 2 menjadi dari 70,83\%dan menjadi 89,58\% pada siklus ketiga.
\end{abstract}

Kata Kunci: Penguasaan Konsep, Kemampuan Siswa, Skrip Kooperatif

\section{PENDAHULUAN}

Manusia

pendidikan dalam

membutuhkan

kehidupannya.

Pendidikan merupakan upaya agar melalui proses pembelajaran dan atau cara lain dikenal dan diakui oleh masyarakat. UUD RI tahun 1945 Pasal 31 ayat (1) Menyebutkan bahwa setiap warga negara berhak mendapatkan pendidikan, dan ayat (3) Menegaskan bahwa Pemerintah mengusahakan

dan

menyelenggarakan saja sistem pendidikan nasional yang meningkatkan keimanan dan ketaqwaan serta akhlak mulia dalam rangka mencerdaskan kehidupan bangsa yang merupakan salah satu tujuan Negara Indonesia.

Gerakan reformasi di Indonesia secara umum menuntut diterapkan prinsip demokrasi, desentralisasi, keadilan, dan menjunjung tinggi hak asasi manusia dalam kehidupan berbangsa dan bernegara.Tuntutan tersebut, dalam bidang pendidikan perlu dilakukan upaya-upaya dalam pembahasan sistem pendidikan, diantaranya pembaharuan kurikulum karena dianggap sudah tidak reprehensif lagi dengan tuntutan dan perkembangan zaman. 
Direktorat TK dan SD Direktorat Jenderal Pendidikan Dasar dan Menengah mengidentifikasi adanya beberapa paradigma baru dalam bidang pendidikan dalam upaya mengatasi berbagai permasalahan pendidikan/ persekolahan yaitu:

1. Menjadikan proses pendidikan dari Schooling ke Learning

2. Menjadikan proses pembelajaran yang bersifat Instruktive je Facilitative

3. Memberikan materi pembelajaran berdasarkan Knowledge Based ke Competence Based.

4. Menjadikan management yang Centralization ke Decentralitation dan

5. Menjadikan masyarakat yang Goverment Role ke Community Role (Masyarakat Madani).

Alasan lain penelitian ini adalah selama Peneliti menjadi guru menemukan bahwa siswa mengalami kesulitan dalam memahami konsep energi karena bersifat abstrak. Energi tidak memiliki massa, tidak dapat diamati, tidak dapat diukur secara langsung, kita hanya dapat mengamati dan merasakan perubahannya. Disamping itu KTSP menekankan adanya penilaian proses bukan hasil akhir, untuk itu sebisa mungkin siswa dibimbing atau dipandu untuk menemukan konsep bukan pembuktian.

Memperhatikan permasalahan adanya pembaharuan pendidikan dan karakteristik pengetahuan alam serta khususnya kesulitan siswa dalam memahami konsep energi panas, maka dalam karya tulis ini Peneliti mengangkat permasalahan sebagai berikut :

1. Apakah belajar menemukan konsep energi panas dengan model pembelajaran melalui Skrip kooperatif dapat meningkatkan hasil belajar siswa kelas VIA SDN. 105292 Percut Sei Tuan?

2. Bagaimana aktivitas siswa kelas VI SDN. 105292 Percut Sei Tuan dalam menemukan konsep energi panas pada model belajar melalui model Pembelajaran Skrip Kooperatif?

Tujuan umum penelitian ini adalah untuk menemukan model pembelajaran yang tepat pada konsep tertentu dalam rangka meningkatkan hasil belajar siswa yang sesuai dengan KTSP. Sedangkan tujuan khusus penelitian ini adalah :

1. Mengetahui peningkatan hasil belajar siswa kelas VIA SDN. 105292Percut Sei Tuan pada konsep energi panas melalui belajar menemukan konsep dengan model pembelajaran Skrip Kooperatif.

2. Mendeskripsikan aktivitas siswa kelas VIA SDN 105292 Percut Sei Tuan dalam belajar menemukan konsep energi panas dengan model pembelajaran Skrip Kooperatif . 


\section{METODE PENELITIAN}

Tempat yang peneliti jadikan pelaksanaan penelitian tindakan kelas ini adalah di SD Negeri 105292 Kecamatan Percut Sei Tuan Tempat penelitian berlokasi di SD Negeri 105292 Kecamatan Percut Sei Tuan Kabupaten Deli Serdang, Penelitian tindakan kelas ini dilaksanakan dalam waktu yang cukup singkat yaitu dalam waktu + Selama 3 bulan yaitu bulan September s/d November 2016.

Populasi dalam penelitian ini adalah seluruh siswa kelas VIA SD Negeri 105292 Kecamatan Percut Sei Tuan Kabupaten Deli Serdang Semester ganjil Tahun Pelajaran 2016/2017 sebanyak 26 siswa

Sumber data penelitian ini adalah :

1. Siswa, untuk mendapatkan data tentang pemahaman siswa.

2. Guru, untuk melihat tingkah laku keberhasilan implementasi pembelajaran pemahaman siswa tentang kompetensi.

3. Teman sejawat atau kolaborator, untuk melihat implementasi penelitian tindakan kelas secara komprehensif, baik dari sisi siswa maupun guru.

Pada penelitian ini, pengumpulan data dilakukan dengan menggunakan teknik sebagai berikut:

a. Test yang dilaksanakan melalui:

1. Pre Test untuk pengumpulan data awal berkenaan dengan kemampuan siswa terhadap materi.

2. Post Test setelah siswa mengikuti suatu proses perlakuan yang dilakukan peneliti, guru memberikan soal-soal post test sehingga didapatkan hasil yang akurat dan dapat menggambarkan secara jelas kemampuan awal dan akhir siswa dalam menguasai materi tersebut.

b. Observasi, dengan menggunakan lembar observasi untuk mengumpulkan data tentang partisipasi dan aktivitas siswa dalam PBM dan implementasi pembelajaran dengan Model Skrip Kooperatif.

c. Diskusi antara guru, teman sejawat dan kolaborator, dengan menggunakan lembar pengamatan untuk refleksi hasil siklus PTK.

Alat pengumpulan data dalam penelitian ini adalah:

1. Tes, digunakan untuk mendapatkan data tentang pemahaman siswa berupa tes tertulis menggunakan butir soal/instrumen soal yang telah dirancang oleh peneliti sesuai dengan tujuan yang telah tertuang dalam kisi-kisi soal untuk mengukur pemahaman siswa sebagai hasil belajar siswa.

2. Observasi, untuk mengumpulkan data tentang partisipasi dan aktivitas siswa dalam PBM dan implementasi pembelajaran 
dengan Model Skrip Kooperatif.

3. Diskusi antara guru, teman sejawat dan kolaborator, untuk refleksi hasil siklus PTK.

Analisis data dilakukan dalam suatu proses yang berarti bahwa pelaksanaannya sudah mulai dilakukan sejak pengumpulan data dan dikerjakan secara intensif sesudah meninggalkan lapangan. (Lexi J. Moleong, 1999: 104). Sedangkan teknik yang digunakan adalah teknik analisis data kualitatif yang dikembangkan oleh Miles dan Huberman (1992: 18-19) yang terdiri dari tiga tahap: (1) mereduksi data; (2) menyajikan data; (3) verifikasi dan menarik kesimpulan.

\section{HASIL DAN PEMBAHASAN}

Penelitian ini dimulai dengan pemberian tes awal yang berfungsi mengukur kemampuan dasar yang dimiliki siswa dan memastikan perlu tidaknya tindakan diberikan pada materi Energi Panas. Berdasarkan hasil tes awal, diperoleh data sebanyak 30 orang siswa telah memenuhi syarat ketuntasan belajar dan 3 orang belum mencapai nilai ketuntasan belajar.

Dari tiga siklus tindakan yang diberikan, dapat dinyatakan bahwa ada peningkatan pemahaman siswa pada Energi Panas. Pada aktivitas siswa terjadi peningkatan, pada siklus 1 hanya $52,08 \%$, meningkat menjadi $70,83 \%$ pada siklus 3 meningkat lagi menjadi $89,58 \%$.
Pada aktivitas guru juga meningkat, dari 59,72\% pada siklus 1 kemudian meningkat lagi menjadi 93,06\% pada siklus 2. Peningkatan aktivitas di atas, menyebabkan pemahaman siswa juga meningkat. Hal ini dapat dilihat dari hasil belajar dalam setiap evaluasi akhir siklus dalam posttest.

Pada Pemahaman siswa pada tes awal hanya $51,82 \%$. Setelah dilakukan tindakan meningkat menjadi $66 \%$ pada siklus 1 , kemudian pada siklus 2 meningkat menjadi pada siklus 3 mencapai $83 \%$. Sesuai dengan indikator kinerja maka penelitian ini telah mencapai nilai aman dan penelitian tidak perlu dilanjutkan lagi.

Perlu diketahui, sampai akhir siklus 2 masih ada nilai 3 orang siswa (10\%) belum mencapai ketuntaan minimal, sehingga diperlukan diberikan perlakuan khusus sehingga nilai siswa tersebut dapat tuntas. Dengan demikian, dari 26 orang siswa, 3 orang siswa $(87 \%)$ dinyatakan telah mencapai nilai ketuntasan minimal.

Peningkatan ini jika dilihat dari tindakan yang dilakukan telah sesuai dengan apa yang diharapkan. Selain meningkatkan aktivitas siswa dalam pembelajaran, perasaan senang juga muncul dari siswa.Dan pemahaman siswa menjadi meningkat.Peningkatan ini diyakini sebagai pengaruh penerapan strategi pembelajaran Skrip Kooperatif yang 
dapat meningkatkan daya ingat dan daya nalar siswa.

\section{SIMPULAN}

Berdasarkan hasil analisis data dan pembahasan Energi Panas dengan metode Skrip Kooperatif pada pelajaran IPA siswa kelas VI A SDN 105292 Percut Sei Tuan dapat disimpulkan sebagai berikut:

1. Pembelajaran Energi Panas pelajaran IPA dengan menggunakan metode Skrip Kooperatif meningkatkan aktivitas pembelajaran, mempertinggi interaksi antar siswa dan guru, serta meningkatkan pemahaman siswa terhadap Energi Panas sehingga kemampuan nalar siswa meningkat.

2. Pembelajaran IPA dengan metode Skrip Kooperatip memacu keberanian siswa sehingga dengan sendirinya rasa minder dan takut bagi siswa tertentu akan hilang, memotivasi siswa untuk lebih aktif dalam pembelajaraan, sehingga pembelajaran semakin hidup, dan memberikan kebebasan pada siswa untuk berkreasi dalam menyelesaikan tugasnya masingmasing.

\section{DAFTAR RUJUKAN}

Sagala, Syaiful. 2009. Konsep dan Makna Pembelajaran.

Bandung: Alfabeta.
Sanjaya, Wina. 2010. Kurikulum dan Pembelajaran. Jakarta: Kencana Prenada Media Group.

Sukarna. 1981. Dasar-Dasar Pendidikan Sains. Jakarta: Batara Karya Husada

Suprijono, Agus. 2010. Cooperative Learning. Teori \& Aplikasi PAIKEM. Yogyakarta: Pustaka Pelajar.

Trianto. 2010. Mendesain Model Pembelajaran InovatifProgresif.Jakarta: Kencana Prenada Media Group.

Usman, Uzer. 2000. Menjadi Guru Profesional. Bandung: PT. Remaja Rosdakarya.

Wena, Made. 2011. Strategi Pembelajaran Inovatif Kontemporer. Jakarta: Bumi Aksara.

Widoko. 2002. Metode Pembelajaran Konsep. Surabaya: Universitas Negeri Surabaya.

Zaini, Hisyam, dkk. 2007. Strategi Pembelajaran Aktif. Yogyakarta: IAIN Sunan Kalijaga. 